Limnol. Rev. (2014) 14,1: 51-60

DOI 10.2478/limre-2014-0006

\title{
Response of cyanobacteria to the fountain-based water aeration system in Jeziorak Mały urban lake
}

\author{
Elżbieta Zębek \\ University of Warmia and Mazury, Faculty of Law and Administration, Law of Environmental Protection Laboratory, Warszawska 98, \\ 10-702 Olsztyn, Poland, e:mail: elzbieta.zebek@uwm.edu.pl
}

\begin{abstract}
This study of cyanobacteria phytoplankton was conducted from May to August in 2002, 2003 and 2005 during fountain-based water aeration in the pelagial of the Jeziorak Mały urban lake in Poland. Additional water mixing by this installation's activity changed the cyanobacterial growth conditions. Although less of their proportion was noted in total phytoplankton abundance, higher mean abundance and biomass were recorded at the fountain than at the lake centre. Higher water temperature in the surface layer favoured cyanobacterial growth at the fountain, while higher iron concentration stimulated their development in the lake's centre. This was supported by positive correlations between their abundance and these water parameters. Moreover, the fountain's activity contributed to the cyanobacteria sinking in the water column. The higher abundance of cyanobacteria was found at $1 \mathrm{~m}$ depth in May, July and August than in the fountain surface layer. Additional water mixing during fountain activity caused also a shift in their abundance maximum (C - June and F - August) and contributed to intensive organic matter decomposition. These conditions promoted cyanobacterial nutrient uptake from the water at the fountain, and this is supported by the negative correlation between their abundance and orthophosphate and total nitrogen concentrations. Generally, water mixing during the fountain's activity does not inhibit the growth of cyanobacteria. This phenomenon disturbed abundance dynamics of the cyanobacteria in summer months but didn't contribute to their abundance decrease. It is important for these results to be considered in future management of shallow urban lakes.
\end{abstract}

Key words: lake, restoration, fountain, cyanobacteria, nutrients

\section{Introduction}

Water eutrophication is accelerated by nutrientenriched inflow, industrial waste and municipal sewage, together with other substances filtering from the catchment area into water bodies (Vollenweider 1971; Bernhardt 1987; Reynolds 2003). Primary production nutrient excess causes massive growth of some algal species, particularly cyanobacteria, and it results in algal blooms (Spodniewska 1986; Bucka 1989).

Water eutrophication processes can be effectively limited by reduction in the inflow of nutrients, especially that of phosphorus and by limitation in its re-suspension from sediments. This can be achieved by various lake restoration methods (Bernhardt 1987; Reynolds 2003; Schrenk-Bergt et al. 2004; Jeppesen et al. 2007; Zheng et al. 2010; Kleeberg et al. 2013). One method applied since 1953 is artificial aeration and mixing of the bottom-waters (Steinberg 1983; Barbiero et al. 1996; Visser et al. 1996; Gafsi et al. 2009; Tof- folon and Serafini 2013). This method has world-wide application, and artificial aeration has been conducted in many Polish lakes; including Lake Długie (Chudyba 1992; Grochowska and Gawrońska 2004), Lake Starodworskie (Lossow et al. 1998), Lake Suskie (Lossow et al. 2004), Lake Mutek (Rybak 1985) and Lake Ełckie (Bańkowska 2007). Artificial water aeration depends on the grout of atmospheric air with pumps to hypolimnion. This aeration and mixing of bottom waters induces organic matter decomposition in oxygenic conditions and favours phosphorus settling in the sediments; and in some cases it even prevents cyanobacterial from blooming (Steinberg 1983; Barbiero et al.1996; Visser et al. 1996; Lossow et al. 1998; Klapper 2003).

Lake Jeziorak Mały is a eutrophic lake with cyanobacteria dominating the phytoplankton. Here, protective-restoration measures, including fountainbased bottom water aeration, were applied to protect 
its waters. It is hypothesized that this fountain-based water aeration through water mixing affected the cyanobacterial growth in summer months. The aim of this paper is to determine the effect of mixing on cyanobacterial abundance from May to August in 2002, 2003 and 2005 during the fountain-based water aeration in Lake Jeziorak Mały.

\section{Study area}

Jeziorak Mały is a shallow eutrophic and polymictic (mean depth $3.4 \mathrm{~m}$ ) urban lake covering 26 ha in the Mazurian Lakeland of north-eastern Poland. The lake is connected with Lake Jeziorak Duży by a narrow canal with a width of $4 \mathrm{~m}$ and depth of $4 \mathrm{~m}$ (Fig. 1). Due to the high disproportion between the surface areas of the lakes (26 ha and 3219 ha, respectively), the connection constitutes a concrete barrier used for water leveling. This is not a factor in the mixing of waters of both lakes. Innovations to improve the lake's water quality began in 1997, and are still ongoing. The most important of these are the installation of separators for storm water pre-treatment by separate petroleum compounds, organic matter and sand from waters flowing in the separated rainwater sewer system; and a fountain-based water aeration system. This fountain installation by Iława city water management authorities now serves two purposes; improved water quality and increased aesthetic and scenic tourism value for Lake Jeziorak Mały. The fountain covered

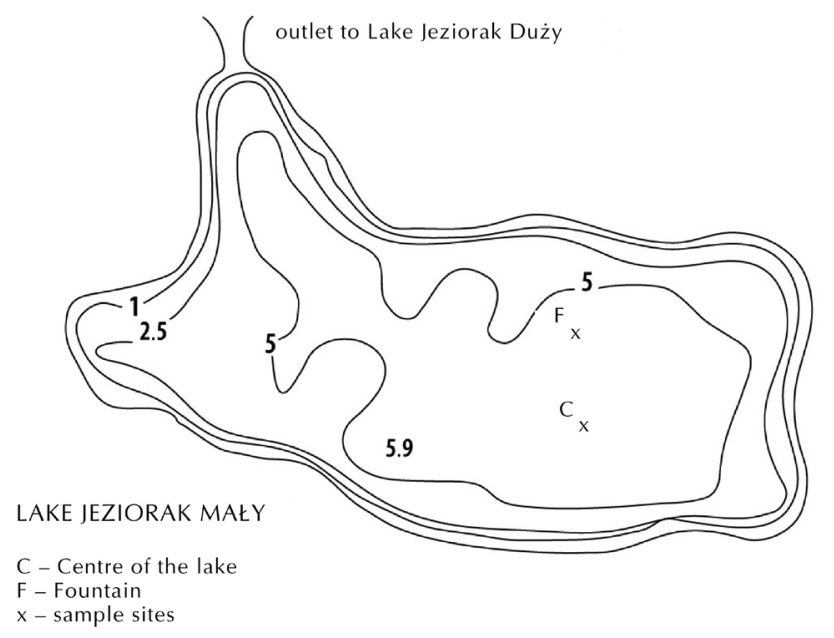

Fig. 1. Morphometric map of Lake Jeziorak Mały (scale 1:2500) both the shore-line and the deeper part of the lake, and subsequent aeration transformed de-oxidized waters from the bottom layer of the $3 \mathrm{~m}$ deep lake-bed to oxygenated water by shooting it $16 \mathrm{~m}$ above the surface and then spraying it over a $3 \mathrm{~m}$ lake cascade area. This results in aeration being limited in the superficial layer to $1 \mathrm{~m}$ depth. The fountain is driven by an SP 60-6 deep pump with $11 \mathrm{KWh}$ power and maximum flow rate of $80 \mathrm{~m}^{3} \mathrm{~h}^{-1}\left(21 \mathrm{dm}^{3} \mathrm{~s}^{-1}\right)$, with a water output volume of $0.14 \mathrm{~m}^{3}$. The rate is therefore $1 \mathrm{~m}^{3}$ every $45 \mathrm{~s}$. This provides $80 \%$ pump efficiency, with water-stream maximum efficiency of $55 \mathrm{~m}^{3} \mathrm{~h}^{-1}$ or $15 \mathrm{dm}^{3} \mathrm{~s}^{-1}$ at 80 $\mathrm{kPa}$ pressure (GRUNDFOS 1997). The waters should be artificially aerated by 11136 hours (about 464 days) to pour the whole volume of the lake.

Based on preliminary studies on phytoplankton conducted in 1996-1999 in Lake Jeziorak Mały, it was observed that restorative measures contributed to improve the quality of the lake's waters (Zębek 2002). The advantage gained from this artificial aeration and increased water mixing was physico-chemical changes in temperature, oxygenation and nutrient concentrations. The lake shores were partly covered with concrete or reinforced with fascine, and most of the sandy bottom was composed of stones and gravel. Lake Jeziorak Mały is therefore an example of a lake with reversed littoral zone management system (approx. $30 \%$ macrophytes, $70 \%$ concrete bank). Phytolittoral includes emerged macrophytes, mainly Phragmites communis, Scirpus lacustris (L.) Palla, Acorus calamus L., and Glyceria aquatica (L.) Wahlb., while the bottom was muddy and covered with decomposing plant debris.

\section{Material and methods}

Phytoplankton samples were collected monthly from May to August in 2002-2003 and 2005 in the pelagial (C - center of lake, and F - fountain) with a Ton 5-liter plankton sampler which provided samples from the surface to $4 \mathrm{~m}$ depth. The samples were poured through a $25 \mu \mathrm{m}$ mesh plankton net, and then preserved with Lugol's solution and a $4 \%$ formaldehyde solution.

In the studies was used the net phytoplankton as fraction dimension above $30 \mu \mathrm{m}$, which is applied by some authors in ecological character works e.g. Vezina and Pace (1994), Nassar and Shams El-Din (2006). Basic physical and chemical water parameters were measured directly in the phytoplankton sam- 
pling sites. Water temperatures with $0.1^{\circ} \mathrm{C}$ precision and oxygen content exact to $0.01 \mathrm{mg} \mathrm{O}_{2} \mathrm{dm}^{-3}$, as indicated by the HI 9143 oxygen meter were determined in situ in the water column from the surface to a depth of $4 \mathrm{~m}$. The dissolved iron $\left(0.005-5.0 \mathrm{mg} \mathrm{Fe} \mathrm{dm}^{-3}\right)$, orthophosphate $\left(0.05-5.00 \mathrm{PO}_{4}^{3-} \mathrm{mg} \mathrm{dm}{ }^{-3}\right)$ ions and total nitrogen ( $\mathrm{TN})$ concentration $\left(0.5-15 \mathrm{mg} \mathrm{N} \mathrm{dm}^{-3}\right)$ were measured in the laboratory using Spectroquant Merck tests with NOVA 400 spectrophotometer.

Qualitative and quantitative determinations of phytoplankton were performed with an Alphaphot YS2 optical microscope. The specimens were counted in a $1 \mathrm{~cm}^{3}$ plankton chamber, and their number is given in $1 \mathrm{dm}^{3}$. In this study, differences in the abundance of cyanobacteria in the lake centre and at the fountain were analyzed. Cyanobacterial biomass was calculated for bio-volume by comparing the algae with their geometric shapes (Rott 1981). The mean biomass was calculated for 10 individuals of each planktonic algae species and also given in $1 \mathrm{dm}^{3}$. For statistical analysis there were counted mean, standard deviation and significance differences $(\mathrm{p}<0.05)$ to determine differences in cynaobacterial abundance and biomass and physico-chemical water parameters between sites in the lake centre and at the fountain.

The abundance of cyanobacteria was correlated with physical and chemical water parameters such as water temperature, oxygen content, $\mathrm{PO}_{4}^{3-}, \mathrm{TN}$ and Fe. Non-parametric methods were used because this data is not normally distributed. These relationships were confirmed by calculating Spearman's rank correlation coefficient by STATISTICA version 8 .

\section{Results}

In Lake Jeziorak Mały in the pelagial, phytoplankton abundance was dominated by cyanobacteria. A 6\% lower proportion of cyanobacteria was found on the surface layer at the fountain $(\mathrm{F})$, with a $21 \%$ lower proportion at $4 \mathrm{~m}$ depth than in the lake centre (C) (Fig. 2). In addition, higher mean of cyanobacterial abundance was recorded at the fountain $\left(73.7 \times 10^{3}-34.0 \times 10^{3}\right.$ ind $\left.\mathrm{dm}^{-3}\right)$ than in the lake's centre $\left(50.9 \times 10^{3}-31.9 \times 10^{3}\right.$ ind $\mathrm{dm}^{-3}$ ), whereas higher mean of biomass was registered in the surface layer at the fountain and at the $4 \mathrm{~m}$ depth in the lake centre; with values 127.2 and $95.7 \times 10^{-3}$ $\mathrm{mg} \mathrm{dm}^{-3}$ and 61.0 and $75.0 \times 10^{-3} \mathrm{mg} \mathrm{dm}^{-3}$, respectively. Standard deviations were lower for abundance and higher for biomass of cyanobacteria than the mean values, but did not exceed twice the mean. Thus indicating that the data was statistically representative. Statistically significant differences were recorded between cyanobacterial abundance and biomass in the surface layer in the lake centre and at the fountain (Table 1).

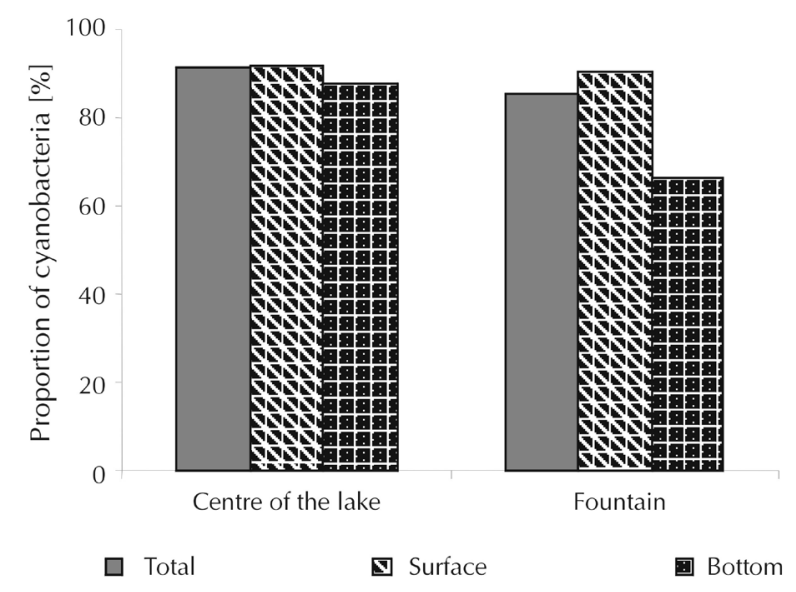

Fig. 2. Proportion of cyanobacteria in the total abundance of phytoplankton in the lake centre (C) and at the fountain (F) in Lake Jeziorak Mały (mean of the years 2002, 2003 and 2005)

Table 1. Abundance and biomass of cyanobacteria and physico-chemical water parameters (mean \pm standard deviation) in pelagial in Lake Jeziorak Mały in 2002, 2003 and 2005

\begin{tabular}{|c|c|c|c|c|}
\hline \multirow{2}{*}{ Parameters } & \multicolumn{2}{|c|}{ Lake's centre $(\mathrm{C})$} & \multicolumn{2}{|c|}{ Fountain $(F)$} \\
\hline & surface & bottom $(4 \mathrm{~m})$ & surface & bottom $(4 \mathrm{~m})$ \\
\hline Abundance $\left(\times 10^{3}\right.$ ind. $\left.\mathrm{dm}^{-3}\right)$ & $50.9^{*} \pm 18.19$ & $31.9 \pm 20.17$ & $73.7^{*} \pm 29.61$ & $34.0 \pm 19.78$ \\
\hline Biomass $\left(\times 10^{-3} \mathrm{mg} \mathrm{dm}^{-3}\right)$ & $95.7^{*} \pm 120.5$ & $75.0 \pm 110.1$ & $127.2^{*} \pm 170.6$ & $61.0 \pm 70.9$ \\
\hline Water temperature $\left({ }^{\circ} \mathrm{C}\right)$ & $22.7 \pm 2.8$ & $14.7 \pm 4.9$ & $23.5 \pm 2.9$ & $14.1 \pm 4.6$ \\
\hline Oxygen content $\left(\mathrm{mg} \mathrm{O}_{2} \mathrm{dm}^{-3}\right)$ & $10.34^{*} \pm 2.68$ & $1.26^{\star} \pm 0.99$ & $8.60^{*} \pm 2.72$ & $0.21^{*} \pm 0.03$ \\
\hline Orthophosphates ( $\mathrm{mg} \mathrm{PO}_{4}^{3-} \mathrm{dm}^{-3}$ ) & $0.30 \pm 0.17$ & $0.49^{*} \pm 0.09$ & $0.25 \pm 0.13$ & $0.37^{*} \pm 0.19$ \\
\hline Total nitrogen $\left(\mathrm{mg} \mathrm{N} \mathrm{dm}^{-3}\right)$ & $2.1 \pm 1.4$ & $3.4^{*} \pm 0.8$ & $2.7 \pm 1.7$ & $4.6^{*} \pm 2.1$ \\
\hline Iron $\left(\mathrm{mg} \mathrm{Fe} \mathrm{dm}^{-3}\right)$ & $5.01 \pm 0.86$ & $4.37 \pm 0.76$ & $4.45 \pm 1.00$ & $4.94 \pm 0.80$ \\
\hline
\end{tabular}

* statistically significant differences $(\mathrm{p}<0.05)$ 
The mean water transparency in 2002-2003 and 2005 was $0.90 \mathrm{~m}$; ranging from 0.45 in May to $0.9 \mathrm{~m}$ in July and August. Water column lower mean temperature was monitored at the fountain compared to that at the lake's centre; with values of 18.9 and $19.4^{\circ} \mathrm{C}$, respectively. For all analyzed water parameters, standard deviations were higher than the mean value. Differences in physico-chemical water parameters were registered at surface layer and bottom of these sites (Table 1). These included, (1) the higher mean water temperature of $23.5^{\circ} \mathrm{C}$ and total nitrogen concentration at $2.7 \mathrm{mg} \mathrm{N} \mathrm{dm}^{-3}$ but lower oxygen content, $\mathrm{PO}_{4}$ and $\mathrm{Fe}\left(8.60 \mathrm{mg} \mathrm{O}_{2} \mathrm{dm}^{-3}, 0.25 \mathrm{PO}_{4}^{3-} \mathrm{mg} \mathrm{dm}^{-3}\right.$ and 4.45 $\mathrm{mg} \mathrm{Fe} \mathrm{dm}^{-3}$ ) recorded in the fountain surface layer compared to the lake centre, and (2) the lower water temperature $\left(14.1^{\circ} \mathrm{C}\right)$, oxygen content and $\mathrm{PO}_{4}(0.21$ $\mathrm{mg} \mathrm{O} \mathrm{dm}^{-3}$ and $0.37 \mathrm{PO}_{4}^{3-} \mathrm{mg} \mathrm{dm}^{-3}$ ) and higher TN and $\mathrm{Fe}$ registered at $4 \mathrm{~m}$ depth in the fountain. Statistically significant differences were recorded between oxygen content in the surface layer and at $4 \mathrm{~m}$ depth, and orthophosphates and total nitrogen at the $4 \mathrm{~m}$ depth in the lake centre and at the fountain.
The following correlations between cyanobacteria abundance and physico-chemical water parameters were recorded in this study: (1) a positive correlation with $\mathrm{Fe}$ in the lake centre $(\mathrm{r}=0.51, \mathrm{p}<0.05)$; (2) a positive correlation with water temperature $(\mathrm{r}=$ $0.40, \mathrm{p}<0.05)$ and oxygen content $(\mathrm{r}=0.33, \mathrm{p}<0.05)$ at the fountain and (3) a negative correlation with $\mathrm{PO}_{4}^{3-}$ $(\mathrm{r}=-0.36, \mathrm{p}<0.05)$ and TN $(\mathrm{r}=-0.50, \mathrm{p}<0.05)$ at the fountain (Table 2).

Table 2. Spearman rank correlation between abundance of cyanobacteria and physio-chemical water parameters $(\mathrm{p}<0.05)$ in pelagial in Lake Jeziorak Mały in 2002, 2003 and 2005

\begin{tabular}{lrr}
\hline \multicolumn{1}{c}{ Parameters } & $\begin{array}{c}\text { Lake's centre }(\mathrm{C}) \\
\mathrm{N}=36\end{array}$ & $\begin{array}{c}\text { Fountain }(\mathrm{F}) \\
\mathrm{N}=36\end{array}$ \\
\hline Water temperature $\left({ }^{\circ} \mathrm{C}\right)$ & $\mathrm{r}=0.31$ & $\mathrm{r}=0.40^{*}$ \\
Oxygen content $\left(\mathrm{mg} \mathrm{O}_{2} \mathrm{dm}^{-3}\right)$ & $r=-0.07$ & $r=0.33^{*}$ \\
Orthophosphates $\left(\mathrm{mg} \mathrm{PO}_{4}{ }^{3-} \mathrm{dm}^{-3}\right)$ & $r=-0.13$ & $r=-0.36^{*}$ \\
Total nitrogen $\left(\mathrm{mg} \mathrm{N} \mathrm{dm}^{-3}\right)$ & $r=0.03$ & $r=-0.50^{*}$ \\
Iron $\left(\mathrm{mg} \mathrm{Fe} \mathrm{dm}^{-3}\right)$ & $r=0.51^{*}$ & $r=0.03$ \\
\hline
\end{tabular}

* statistically significant
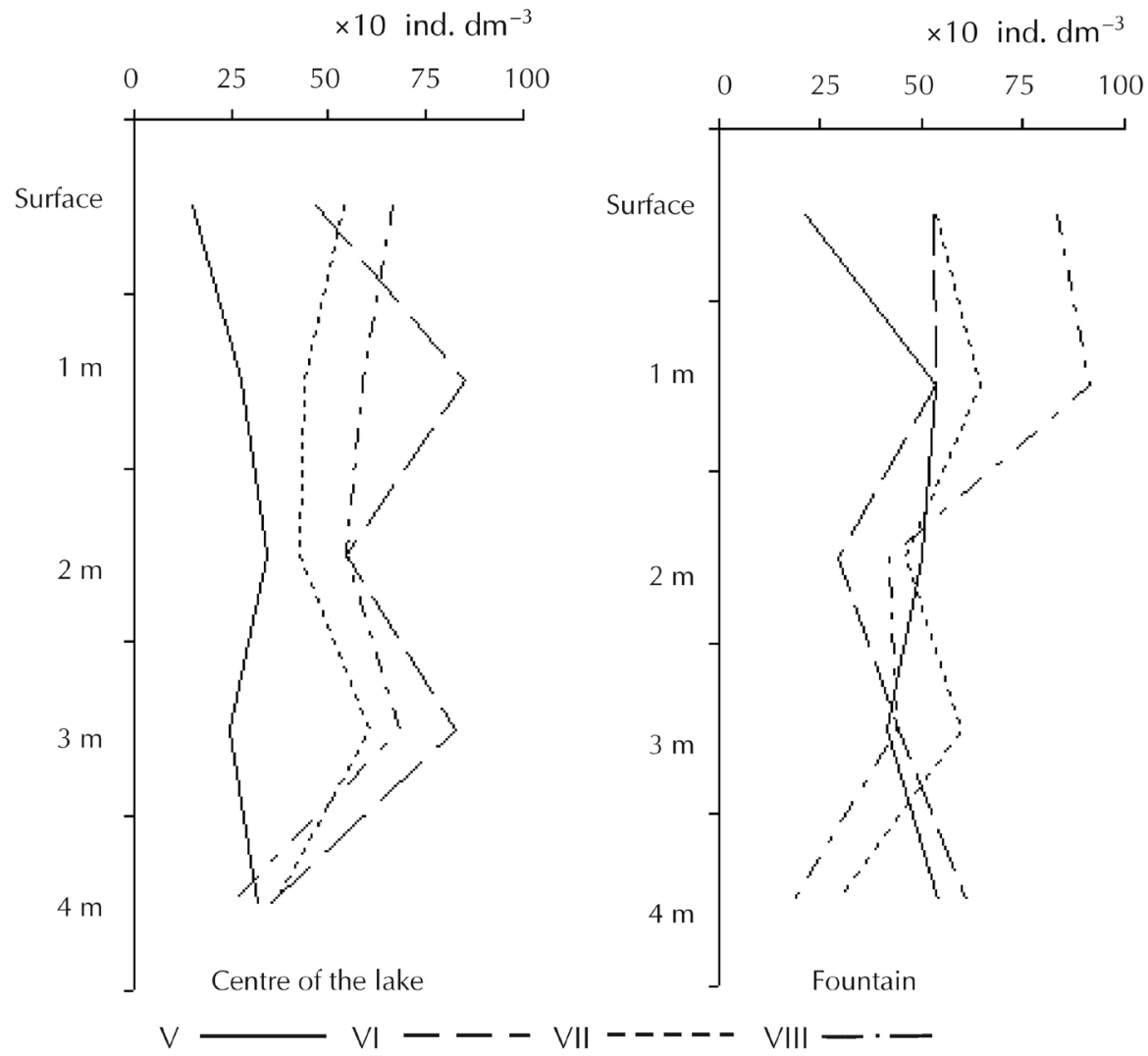

Fig. 3. Dynamics of cyanobacteria abundance $\left(\times 10^{3}\right.$ ind. $\left.\mathrm{dm}^{-3}\right)$ in water column from May to August in Lake Jeziorak Mały (mean of the years 2002, 2003 and 2005) 

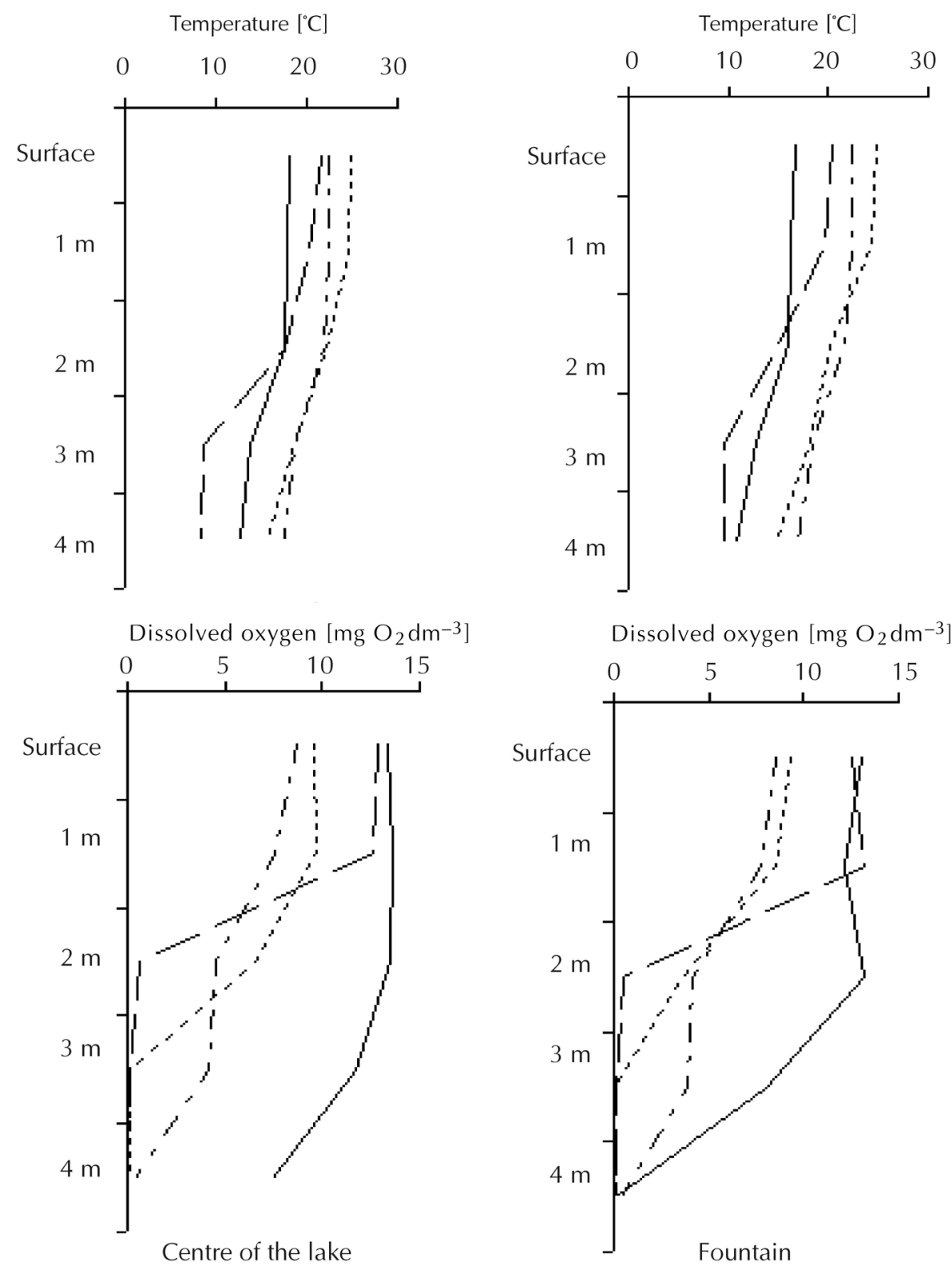

$\mathrm{V} \longrightarrow \mathrm{VI}--\mathrm{VII}$

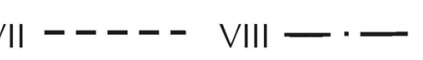

Fig. 4. Water temperature and oxygen content in water column from May to August in Lake Jeziorak Mały (mean of the years 2002,2003 and 2005)

Among cyanobacteria dominated Planktolyngbya brevicellularis Cronberg \& Komarek, accompanied by Aphanizomenon gracile Lemm., Planktothrix agardhii (Gomont) Anagnostidis \& Komárek, Pseudanabaena limnetica (Lemm.) Komárek and Limnothrix redekei (Van Goor) Meffert. In the total abundance of cyanobacteria it was recorded a decrease in the proportion of $P$. brevicellularis from 92.51 to $81.14 \%$ in the lake centre and from 93.98 to $76.40 \%$ at the fountain in the years 2001, 2003 and 2005. However, it was simultaneously observed a significant increase in the proportion of A. gracile, P. agardhii and P. limnetica (Table 3).

In addition, differences in physico-chemical water parameters and cyanobacteria abundance were ob- 
Table 3. Dominant species (\%) in the total abundance of cyanobacteria in pelagial in Lake Jeziorak Mały in 2002, 2003 and 2005

\begin{tabular}{|c|c|c|c|c|c|c|}
\hline \multirow{2}{*}{$\begin{array}{l}\text { Species } \\
\text { Years }\end{array}$} & \multicolumn{3}{|c|}{ Lake's centre $(\mathrm{C})$} & \multicolumn{3}{|c|}{ Fountain (F) } \\
\hline & 2002 & 2003 & 2005 & 2002 & 2003 & 2005 \\
\hline Planktolyngbya brevicellularis Cronberg \& Komárek & 95.21 & 92.69 & 81.14 & 93.98 & 92.51 & 76.40 \\
\hline Aphanizomenon gracile Lemm. & 7.19 & 2.36 & 8.07 & 6.37 & 2.89 & 7.89 \\
\hline Planktothrix agardhii (Gomont) Anagnostidis \& Komárek & 0.12 & 0.12 & 7.38 & 0.16 & 0.16 & 10.81 \\
\hline Pseudanabaena limnetica (Lemm.) Komárek & 0.05 & 4.04 & 3.22 & 0.04 & 4.56 & 4.72 \\
\hline Limnothrix redekei (Van Goor) Meffert & 0.05 & 0.74 & 0.16 & 0.01 & 0.20 & 0.01 \\
\hline
\end{tabular}

served from May to August in the water column. The lowest water temperature $\left(16.8^{\circ} \mathrm{C}\right)$ was in May and the highest water temperature of $24.8^{\circ} \mathrm{C}$ in July. Minimum oxygen contents were found at $2 \mathrm{~m}$ depth in June, at $3 \mathrm{~m}$ in July and at $4 \mathrm{~m}$ in August. In addition, oxygenation decreased at $4 \mathrm{~m}$ in May at the fountain. Somewhat higher oxygen content of $13.16 \mathrm{mg} \mathrm{O}_{2} \mathrm{dm}^{-3}$ at $1 \mathrm{~m}$ water depth at the fountain occurred in June than in the lake centre (Fig. 4). The lowest abundance of cynaobacteria at both the fountain and the lake centre was found in May $\left(26.5 \times 10^{3}\right.$ and $44.0 \times 10^{3}$ ind. $\mathrm{dm}^{-3}$, respectively) whereas their maximum abundance occurred in June $\left(\mathrm{C}-60.8 \times 10^{3}\right.$ ind. $\left.\mathrm{dm}^{-3}\right)$ and August $\left(\mathrm{F}-55.7 \times 10^{3}\right.$ ind. $\left.\mathrm{dm}^{-3}\right)$. Moreover, an increase in cyanobacteria abundance was observed at $1 \mathrm{~m}$ (C - June and F - May, July and August) and 3m depths (C - July and August and F - June) (Fig. 3). While increasing orthophosphate levels accompanied increasing water depths in May and July in the lake centre, $\mathrm{PO}_{4}^{3-}$ decreased in July at the fountain. A general decrease in total nitrogen concentration in the water column was observed in the lake centre, together with increased $\mathrm{TN}$ at the fountain (Fig. 5).

\section{Discussion}

Based on studies on phytoplankton conducted in 1978, Lake Jeziorak Mały was qualified as a polytrophic lake. Dominance of cyanobacteria amounted to more than $90 \%$ of total phytoplankton biomass in the summer season (Spodniewska 1996). In 19951996, before the implementation of protective-restoration measures in the surface layer of the pelagial, the mean proportion of cyanobacteria equalled $92.83 \%$. Prior to this, phytoplankton had been dominated by Limnothrix redekei (Zębek 1998; 2009), which is typical in strongly eutrophic lakes (Wernicke and Nicklish 1986; Oberholster et al. 2006). When the fountain functioned in lake Jeziorak Mały in 2002, 2003 and 2005 , the mean proportion of cyanobacteria decreased to $78.26 \%$ in the pelagial. Plaktolyngbya brevicellularis, which is typical in eutrophic lakes (Cronberg and Komárek 1994; Zębek 2006), dominated here; accompanied by Aphanizomenon gracile, Planktothrix agardhii, Pseudanabaena limnetica and Limnothrix redekei. Moreover, a decrease in the proportion of $P$. brevicellularis and an increase in A. gracile, $P$. agardhii and $P$. limnetica in the total abundance of cyanobacteria can certainly be related to water disturbances especially at the fountain. Intensified cyanobacterial growth was often noted in summer months, and its dominance of $80-90 \%$ in the pelagial in this period favourably compared with other studies examining eutrophic lakes (Teubner et al. 1999; Schrenk-Bergt et al. 2004; Kangro et al. 2005). Some authors also observed decreased cyanobacteria percentages resulting from the artificial aeration witnessed in Lake Jeziorak Mały (Chudyba 1992; Visser et al. 1996; Oberholster et al. 2007). A lower mean proportion of cyanobacteria was found at the fountain $(\mathrm{F})$ than at the lake centre (C), both in the surface layer and on the bottom at a depth of $4 \mathrm{~m}$ (Fig. 2). This suggests that the decreased cyanobacteria proportion in the summer seasons of years following the fountain's installation could be related to changes in conditions for cyanobacteria growth due to water mixing.

Differences in physico-chemical water parameters were observed in this study after the fountain began functioning. Results here were similar to those of Gächter (1987); Bürgi and Stadelmann (2002) and Grochowska and Gawrońska (2004), with decreased mean othophosphate concentration from $0.51 \mathrm{PO}_{4}^{3-}$ $\mathrm{mg} \mathrm{dm}{ }^{-3}$ in 1996-1999 to $0.43 \mathrm{mg} \mathrm{PO}_{4}^{3-} \mathrm{mg} \mathrm{dm}^{-3}$ in 2002, 2003 and 2005. Moreover, lower $\mathrm{PO}_{4}^{3-}$ was recorded at the fountain in both the surface layer and the bottom of this lake compared to the lake's centre (Table1). This phenomenon is related to the following; (1) artificial aeration causing intensive decomposition of organic matter (2) improved sanitation in the catchment area, and (3) implementation of the auxil- 


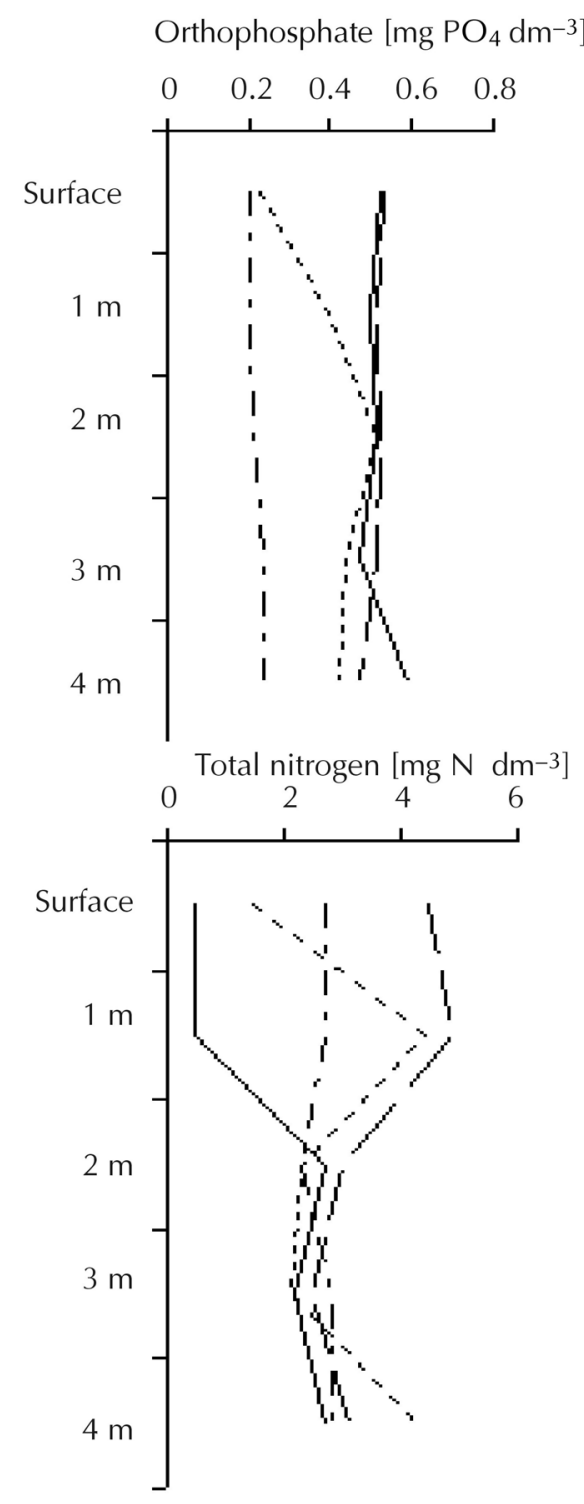

Centre of the lake
Orthophosphate $\left[\mathrm{mg} \mathrm{PO}_{4} \mathrm{dm}^{-3}\right]$
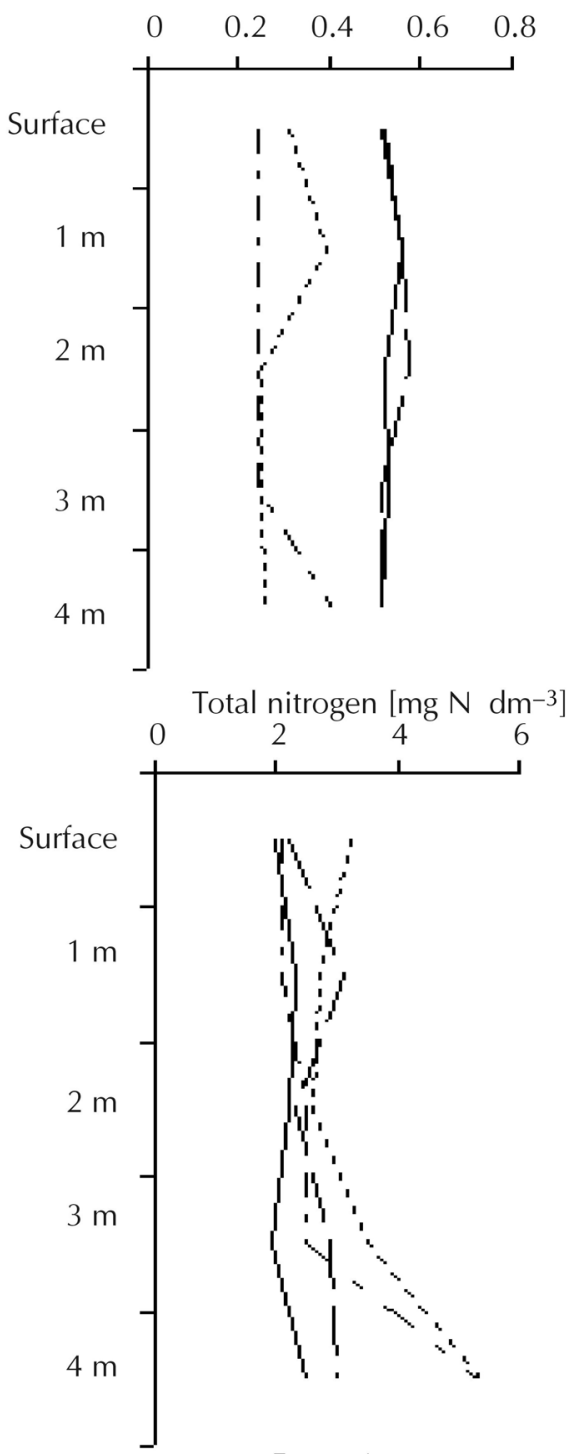

Fountain $\mathrm{V} \longrightarrow \mathrm{VI}--\mathrm{VII}----\mathrm{VIII}-\cdot-$

Fig. 5. Orthophosphate and total nitrogen concentrations from May to August in Lake Jeziorak Mały (mean of the years 2002, 2003 and 2005)

iary restorative measures of separator installation, and the accumulation of stones which provided a habitable substrate for periphytic algal nutrient uptake from the lake's water. In this study, the lower mean water column temperature at the fountain compared to that in the lake centre was caused by intensive cool water mixing in the bottom layer prior to it being sprayed above the surface. In addition, a higher mean total nitrogen, together with lower oxygenation and $\mathrm{Fe}$, were observed in the surface layer at the fountain compared to the lake's centre, with also lower water temperature, oxygenation and $\mathrm{PO}_{4}^{3-}$ but higher $\mathrm{TN}$ and $\mathrm{Fe}$ at the bottom. Significant differences between oxygen content in the surface layer and at $4 \mathrm{~m}$ depth, and orthophosphates and total nitrogen at the $4 \mathrm{~m}$ depth in the lake centre and at the fountain (Table 1) can certainly be related to the intensified water mixing created by the fountain which enhanced cyanobacteria growth 
conditions. Mass growth of the prokaryotic organisms depends on water temperature, nutrient resources (particularly phosphorus and nitrogen), the degree of exposure to wind and mixing, phosphorus resuspension from sediments (Vollenweider 1968; Wernicke and Nicklisch 1986; Reynolds 1984; Barbiero et al.1996; Berman-Frank et al. 2007) and iron accessibility (Burchardt et al. 2007; El-Sayed et al. 2010). As apparent in Lake Jeziorak Mały, the cited authors also observed relationships between algal abundance and water temperature and nutrients; noting increased cyanobacterial abundance with increasing water temperature. In this study, higher cyanobacterial abundance and biomass were recorded at the fountain than in the lake centre. Statistically significant differences between these values in the surface layer (Table 1) are most likely related to the different growth conditions for the cyanobacteria at these sites. According to Teubner et al. (1999), $\mathrm{P}$ and $\mathrm{N}$ nutrients don't affect the growth of cyanobacteria in the following situations: (1) when amount so high values (ad libitum) similar to those of Lake Jeziorak Mały (Zębek 2005; Table 1), and (2) when the TN:TP ratio drops to a critical value. This suggests that orthophosphates and total nitrogen had less influence in their development than water temperature, other elements $(\mathrm{Fe})$ and water mixing and disturbances. Thus higher water temperature in the surface layer favoured cyanobacteria growth at the fountain, while higher iron concentration stimulated their development in the lake's centre. This conclusion is supported by the positive correlation between their abundance and these water parameters (Table 2).

Disturbances in cyanobacterial biomass growth can also be caused by environmental stress, such as that imposed by decreased water temperature or strong water mixing (Burchardt and Pawlik-Skowrońska 2005). This phenomenon occurred in the polymictic Jeziorak Mały lake where a higher coefficient of mixing was recorded (Zębek 2009). Additional water mixing during fountain operation contributed to sudden changes in the physico-chemical water parameters, and thus disturbance of cyanobacterial growth during the summer months. Here, in this study, a rapid decrease in algal abundance with water depth and decreased water temperature was found in August at the fountain (Figs. 3, 4). The artificial water mixing in this lake delayed cyanobacterial mass growth. Similar results recorded Visser et al. (1996). Although the maximum cyanobacteria abundance in the lake centre was noted in June, this occurred only during August at the fountain. Moreover, differences in cyanobacteria abundance in the water column, including increased abundance at $1 \mathrm{~m}$ depth in June and $3 \mathrm{~m}$ depth in July and August, were observed in the lake's centre. In contrast, the opposite situation was recorded at the fountain (Fig. 3). The higher abundance of cyanobacteria found at $1 \mathrm{~m}$ depth in May, July and August compared to the number registered at the fountain surface indicated the cyanobacteria sinking in the water column.

Water mixing contributed to improvement conditions of organic matter decomposition processes, its intensified and deficits of oxygen on the lake bed, especially at the fountain where this finding was supported by lower mean oxygen content (Table 1) and oxygen deficit. Matinvesi (1996) also recorded summer oxygen deficits at the bottom of the water body during artificial aeration. In this study, minimal oxygen contents were recorded from $2 \mathrm{~m}$ in June to $4 \mathrm{~m}$ in August. Moreover, the oxygen deficit registered at $4 \mathrm{~m}$ at the fountain in May (Fig. 4) is related to possible sedimentary disturbance during this additional water mixing. The increased aeration effect on oxygen at the fountain was noted only in June; with higher oxygen content recorded there compared to the lake's centre in that month (Fig. 4).

In this study, differences in nutrient concentrations were observed in the water column in the summer months. Intensive water mixing in shallow lakes generally leads to $\mathrm{PO}_{4}^{3-}$ re-suspension from the sediments (Dokulil and Teubner 2003). The increased orthophosphate levels with increasing water depth in May and July in the lake centre, as depicted in Figure 5 , may indicate their re-suspension from sediments. However, the opposite situation was recorded at the fountain, where decreased $\mathrm{PO}_{4}^{3-}$ was noted in the water column during artificial aeration in July (Fig. 5). This phenomenon was also reported by Lossow et al. (1998). As witnessed in Lake Jeziorak Mały, other authors have observed cyanobacterial dominance at low orthophosphate concentrations in shallow eutrophic lakes (Jensen et al. 1994; Morris et al. 2006). According to Bańkowska (2007), this phenomenon may be related to phosphorus assimilation by cyanobacteria during water aeration. Results from this present study suggest that the decreased orthophosphate levels at the fountain indicate its uptake by cyanobacteria (Table 2). 


\section{Conclusion}

In Lake Jeziorak Mały, the fountain's contribution to water aeration through additional water mixing influenced the cyanobacterial growth conditions. Higher water temperature in the surface layer favoured cyanobacteria growth at the fountain, while higher iron concentration stimulated their development in the lake's centre. Thus the prokaryotic organisms attached high abundance at the fountain. Moreover, the fountain's activity contributed to cyanobacterial sinking in the water column. An intensive water mixing caused disturbances to algal dynamics in the summer months and also delayed maximum algal abundance at the fountain. This additional water mixing intensified also organic matter decomposition in the sediments, thus enhancing cyanobacterial uptake of nutrients from the water and consequent decrease in $\mathrm{PO}_{4}^{3-}$ at the fountain. Generally, water mixing during the fountain's activity is not inhibiting the growth of phytoplankton dominated by cyanobacteria in Lake Jeziorak Mały. Here, it changed only the structure of cyanobacteria with the decrease in their percentage but didn't contribute to the decrease in their abundance. These study results suggest that this type of phenomenon should be considered during the planning of protective - restoration works of water bodies, especially in future management strategies for urban shallow lakes.

\section{References}

Bańkowska A., 2007, Ocena działania struktur BIO-HYDRO w rekultywacji Jeziora Ełckiego (Performance evaluation of the BIO-HYDRO structures in recultivation of the Ełckie Lake), Prz. Nauk. - Inż. Kształt. Środ. 38(4): 21-28.

Barbiero R.P., Speziale B.J., Arshby S.L., 1996, Phytoplankton community in a lake subjected to artificial circulation, Hydrobiologia 331: 109-120.

Bernhardt H., 1987, Strategies of lake sanitation, Shweiz. Z. Hydrol. 49(2): 202-219.

Berman-Frank I., Quigg A., Finkel Z.V., Irwin A.J., Haramaty L., 2007, Nitrogen-fixation strategies and Fe requirements in cyanobacteria, Limnol.Oceanogr. 52(5): 2260-2269.

Bucka H., 1989, Ecology of selected planktonic algae causing water blooms, Acta Hydrobiol. 31(3/4): 207-258.

Burchardt L., Pawlik-Skowrońska B., 2005, Blue-green algal blooms - interspecific competition and environmental threat, Wiad. Biol. 49(1/2): 39-49.
Burchardt L., Marshall H.G., Kokociński M., Owsianny P.M., 2007, Blooms of Aphanizomenon flos-aquae associated with historical changes occurring in Lake Świętokrzyskie, Poland, Oceanol. Hydrobiol. Stud. 36(1): 261-266.

Bürgi H., Stadelmann P., 2002, Change of phytoplankton composition and biodiversity in Lake Sempach before and during restoration, Hydrobiologia 469: 33-48.

Chudyba H., 1992, Zmiany struktury fitoplanktonu w trakcie sztucznego napowietrzania Jeziora Długiego w Olsztynie, Acta Acad. Agricult. Tech. Olst. 19: 131-149.

Cronberg G., Komarek J., 1994, Planktic Cyanoprokaryotes found in South Swedish lakes during the XIIth International Symposium on Cyanophyte Research, 1992, Algological Stud. 75: 323-352.

Dokulil M.T., Teubner K., 2003, Eutrophication and restoration of shallow lakes - the concept of stable equilibria revisited, Hydrobiologia 506-509: 29-35.

El-Sayed A.B., El Fouly M.M., Ghazy S.M., El Semary N.A., Hassoub M.A., 2010, Some growth metabolites of two cyanobacteria species as affected by mineral nutrition, Nat. Sci. 8(12): 20-28.

Gafsi M., Kettab A., Benmamar S., Benziada S., 2009, Comparative studies of the different mechanical oxygenation systems used in the restoration of lakes and reservoirs, J. Food Agric. Environ. 7(2): 815-822.

Gächter R., 1987, Lake restoration. Why oxygenation and artificial mixing cannot substitute for a decrease in the external phosphorus loading, Swiss J. Hydrol. 49(2): 170-185.

Grochowska J., Gawrońska H., 2004, Restoration effectiveness of a degraded lake using multi-year artificial aeration, Pol. J Environ. Stud. 13(6): 671-681.

GRUNDFOS, 1997, Functioning scheme of fountain (material records).

Jensen J.P., Jeppesen E., Orlik K., Kristensen P., 1994, Impact of nutrients and physical factors on the shift from cyanobacterial to chlorophyte dominance in shallow Danish Lakes, Can. J Fish. Aquat. Sci. 51: 1692-1699.

Jeppesen E., Sondergaard M., Meerhoff M., Lauridesen T.L., Jensen J.P., 2007, Shallow lake restoration by nutrient loading reduction - some recent findings and challenege ahead, Hydrobiologia 584: 239-252.

Kangro K., Laugaste R.., Noges P., Ott I., 2005, Long-term changes and seasonal development of phytoplankton in a strongly stratified, hypertrophic lake, Hydrobiologia 547: 91-103.

Klapper H., 2003, Techologies for lake restoration, J. Limnol. 62(1): 73-90.

Kleeberg A., Herzog C., Hupfer M., 2013, Redox sensitivity of iron in phosphorus binding does not impede lake restoration, Water Res. 47(3): 1491-1502.

Lossow K., Gawrońska H., Jaszczułt R., 1998, Attempts to use wind energy for artificial destratification of Lake Starodworskie, Pol. J. Environ. Stud. 7: 221-227.

Lossow K., Gawrońska H., Łopata M., Jaworska B., 2004, Selection criteria for restoration method on Lake Suskie, Limnol. Rev. 4: 143-152. 
Matinvesi J., 1996, The change of sediment composition during recovery of two Finnish lakes induced by waste water purification and lake oxygenation, Hydrobiologia 335(3): 193-202.

Morris K., Bailey P.C.E., Boon P.J., Hughes L., 2006, Effects of plant harvesting and nutrient enrichment on phytoplankton community structure in a shallow urban lake, Hydrobiologia 571: 77-91.

Nassar M.Z., Shams El-Din N.G., 2006, Seasonal dynamics of phytoplankton community in the Bitter Lake and Temsah Lake, Egypt, J. Aqua. Res. 32: 198-219.

Oberholster P.J., Botha A-M, Cloete T.E., 2006, Toxic cyanobacterial blooms in a shallow, artificially mixed urban lake in Colorado, USA, Lakes Reserv. Res. Manage. 11(2): 111-123.

Oberholster P.J., Botha A-M, Cloete T.E., 2007, Ecological implications of artificial mixing and bottom-sediment removal for a shallow urban lake, Lake Sheldon, Colorado, Lakes Reserv. Res. Manage. 12(2): 73-86.

Reynolds C.S., 1984, Phytoplankton periodicity: the interaction of form, function and environmental variability, Freshwat. Biol. 14: 111-142.

Reynolds C.S., 2003, The development of perceptions of aquatic eutrophication and its control, Ecohydrol. Hydrobiol. 3(2): 149-163.

Rott E., 1981. Some results from phytoplankton counting intercalibrations, Shweiz. Z. Hydrol. 43: 34-62.

Rybak M., 1985, Some ecological effects of artificial circulation on the phytoplankton, Hydrobiologia 122(1): 89-96.

Schrenk-Bergt C., Krause D., Prawitt O., Lewandowski J., Steinberg C.E.W., 2004, Eutrophication problems and their potential solutions in the artificial shallow Lake Altmühlsee (Germany), Studia Quaternaria 21: 73-86.

Spodniewska I., 1986, Planktonic blue-green algae of lakes in north-eastern Poland, Ekol. Pol. 34(2): 151-183.

Steinberg C., 1983, Effects of artificial destratification on the phytoplankton populations in a small lake, J. Plankton Res. 5: 855-864.

Teubner K., Feyerabend R., Henning M., Nicklisch A., Woitke P., Kohl J.-G., 1999, Alternative blooming of Aphanizomenon flos-aquae or Planktothrix agardhii induced by the timing of the critical nitrogen : phosphorus ratio in hypertrophic riverine lakes, Arch. Hydrobiol. Spec. Issues Advanc. Limnol. 54: 325-344.
Toffolon M., Serafini M., 2013, Effects of artificial hypolimnetic oxygenation in a shallow lake. Part 2: Numerical modeling, J. Environ. Manage. 114: 530-539.

Vezina A.F., Pace M.L., 1994, An inverse model analysis of planktonic food webs in experimental lakes, Can. J. Fish. Aquat. Sci. 51: 2034-2044.

Visser P.M., Ibelings B.W., Veer B., Koedod J., Mur L.R., 1996, Artifical mixing prevents nuisance blooms of the cyanobacterium Microcystis in Lake Nieuwe, the Netherlands, Freshwat. Biol. 36: 435-450.

Vollenweider R.A., 1971, Scientific fundamentals of the eutrophication of lakes and following waters, with particular reference to nitrogen and phosphorus as factors in eutrophication, OECD, Paris, p. 61.

Wernicke P., Nicklisch A., 1986, Light/dark cycle and temperature - their impact on phosphate - limited growth of Oscillatoria redekei van Goor in semicontinuous culture, Int. Revue ges. Hydrobiol. Hydrogr. 71(3): 297-313.

Zheng Z., Song G. ,Zhou Z., Han X., Teng M. ,Li Z., 2010, Classified conservation and restoration of vegetation in Wuhan urban lake wetlands based on plant diversity characteristics, Acta Ecologica Sinica 24: 7045-7054.

Zębek E., 1998, Water temperature of the littoral zone during the domination of the blue-green algae Planktothrix agardhii and Limnothrix redeckei in the composition of phytoplankton in the polytrophic lake Jeziorak Mały, Oceanol. Stud. 1: 53-59.

Zębek E., 2002, Wpływ zabiegów rekultywacyjnych na fitoplankton w śródmiejskim jeziorze Jeziorak Mały (Influence of the rehabilitation treatments on the phytoplankton in the urban Lake Jeziorak Mały) [dissertation], Wydz. Prawa i Administracji UWM, Olsztyn, p. 67.

Zębek E., 2005, Qualitative and quantitative changes of blue-green algae in response to physicochemical water parameters in the urban lake Jeziorak Mały, Oceanol. Hydrobiol. Stud. 34(1): 39-56.

Zębek E., 2006, Quantitative changes of Planktolyngbya brevicellularis, Limnothrix redekei and Aphanizomenon gracile in the annual cycle vs. physicochemical water parameters in the urban Lake Jeziorak Mały, Oceanol. Hydrobiol. Stud. 35(1): 69-84.

Zębek E., 2009, Seasonal changes in net phytoplankton in two lakes with differing morphometry and trophic status (northeast Poland), Archives of Polish Fisheries 17: 267-278. 